\title{
NEEM (AZADIRACHTA INDICA A. JUSS) AS A SOURCE FOR GREEN SYNTHESIS OF NANOPARTICLES
}

\section{GIRISH K*}

Department of Microbiology, Maharani’s Science College for Women, Mysuru - 570 008, Karnataka, India. Email: girishk77@yahoo.com Received: 17 October 2017, Revised and Accepted: 06 December 2017

\begin{abstract}
Nanoscience has found various applications in different biomedical fields. The synthesis of nanoparticles (NPs) has become a vast area of research due to its potential applications. These particles can be prepared by different chemical, physical, and biological approaches. In recent years, green synthesis of NPs using plant extracts has gained much interest due to non-toxicity and very low cost of synthesis. The plant extracts act both as reducing agent as well as capping agent. Neem (Azadirachta indica A. Juss) is a well-known medicinal plant and has been studied for the biosynthesis of NPs. A. indica has various phytochemicals identified that can reduce the metal ions. The bioreduction of NPs from neem extract is an eco-friendly, low cost, and green synthesis method and these NPs are reported to exhibit good antimicrobial, mainly antibacterial, activity.
\end{abstract}

Keywords: Azadirachta indica, Neem, Nanoparticles, Antimicrobial activity.

(C) 2018 The Authors. Published by Innovare Academic Sciences Pvt Ltd. This is an open access article under the CC BY license (http://creativecommons. org/licenses/by/4. 0/) DOI: http://dx.doi.org/10.22159/ajpcr.2018.v11i3.21939

\section{INTRODUCTION}

Nanotechnology is an emerging interdisciplinary field which mainly concerns with the fabrication of nanoparticles (NPs) with specific requirements in terms of size, shape, and controlled dispersity. The field of nanotechnology is one of the most active research areas in modern material science. Over the last few decades, the syntheses of novel metal NPs have been the subject of many applied researches due to their unique properties [1]. "Nano" is used to indicate 1 billionth of a meter (or) $10^{-9}$ [2]. In general, particles with a size $<100 \mathrm{~nm}$ are referred to as NPs. The "Nano" is derived from the Greek word for dwarf and is also related to the Spanish word Nino [3]. In nanotechnology, a nanoparticle is defined as a small object that behaves as a whole unit in terms of its transport and properties [4]. This technology presently has attracted various branches of application due to the dissimilar behavior of the bulk material when reduced to its nanosize [5].

The distinctive properties of nanomaterials are mainly influenced by size, shape, interactions with stabilizers, media, and methods of synthesis $[1,6]$. Therefore, controlled synthesis of NPs with respect to their size, shape, and stability is a key challenge to reach their better applied characteristics [1]. In general, metal NPs can be prepared and stabilized by chemical, physical, and biological methods; the chemical approach, such as chemical reduction, electrochemical techniques, photochemical reduction [7-9], and pyrolysis [10]; and physical methods such as arc discharge and physical vapor condensation [11] are used. However, many of these nanoparticle synthesis methods involve the use of hazardous chemicals or high energy requirements, which are rather difficult and include wasteful purifications [12]. Biological systems such as the use of plant materials provide an innovative, ecofriendly alternative for the production of NPs [13]. Biosynthesis using plant sources offers several advantages such as cost-effectiveness, ecofriendliness, and the elimination of high pressure, energy, temperature, and toxic chemicals necessary in the traditional synthesis methods [14]. Plants provide a better platform for nanoparticle synthesis as they are free from toxic chemicals as well as provide natural capping agents [15]. The plant extracts contain various organic compounds such as terpenoids that aid nanoparticle synthesis. Terpenoids are surface-active molecules that help to stabilize the NPs [16].

Microorganisms can also be utilized to produce NPs, but the rates of syntheses are slow compared to routes involving plants mediated synthesis [12]. Many bacterial cultures were used for different kind of NPs such as gold NPs using Shewanella algae, a marine bacterium [17] and actinomycetes Thermomonospora sp., [18] and Streptomyces viridogenes strain HM10 [19], silver NPs (AgNPs) by cyanobacteria Plectonema boryanum [20] and by fungi Aspergillus fumigatus [21], Trichoderma asperellum [22], and Fusarium oxysporum [7,23], Fusarium udum, and Stemphylium vericans [23]; cadmium NPs biosynthesis was done by Clostridium thermoaceticum, magnetite NPs by Actinobacteria sp., and uranium NPs by Shewanella oneidensis [24], titanium dioxide NPs using bacteria Lactobacillus sp., [25] and Bacillus subtilis [26].

Biosyntheses of NPs using extracts from various plants such as Aloe vera [27], Jatropha curcas [28], Acalypha indica [29], Sesuvium portulacastrum [30], Garcinia mangostana [31], Ocimum tenuiflorum [32,33], Abutilon indicum, Melia dubia [34], Solanum trilobatum [35], Musa balbisiana [33], Crataegus douglasii [36], Beta vulgaris (beet root) [37], Tagetes erecta (marigold) [38], Ziziphora tenuior [39], Carica papaya [40], Digitaria radicosa [41], and Lantana camara [42], have been reported in literature with nanoparticle size ranging from 5 to $20 \mathrm{~nm}$. However, the potential of higher plants as source for this purpose is still largely unexplored.

\section{NPS SYNTHESIS USING NEEM EXTRACT}

Extracts from neem ( $A$. indica) plant have been used for greener synthesis of NPs $[16,43,44]$. The major advantage of using the neem leaves is that it is a commonly available medicinal plant and known to have antimicrobial activity [45]

Gold NPs were synthesized using neem leaf extract and the synthesis was confirmed by color changes and characterized by ultraviolet (UV)-visible spectroscopy [46,47]. Gold NPs were synthesized by mixing aqueous extract of neem leaves and $10^{-3} \mathrm{M}$ aqueous chloroauric acid $\left(\mathrm{HAuCl}_{4}\right)$. Isomorphic spherical gold NPs of 15-18 $\mathrm{nm}$ in size were synthesized [48]. Gold NPs were synthesized using neem leaf extract and $2 \%$ auric chloride solution $\left(\mathrm{AuCl}_{4}\right)$ and were characterized [43].

Using neem leaf extract, researchers produced platinum NPs from chloroplatinic acid. The solution color changed from light yellow to black on heating, indicating the formation of platinum NPs. The NPs were between 5 and $50 \mathrm{~nm}$ in diameter. These platinum NPs are 
potentially useful in the bioelectronics and chemical industries for various medicinal and catalytic applications [16].

Zerovalent iron NPs were synthesized from the leaf extract of the neem plant. The diameter of iron NPs was within the range of 50-100 nm [49]. Spherical-shaped iron oxide particles ranging in size from 10 to $20 \mathrm{~nm}$ were synthesized by simple coprecipitation method. The synthesized NPs were stabilized by biocapping with aqueous leaf extract of neem. The antimicrobial activity of neem extract capped magnetite NPs was evaluated against Bacillus sp., Staphylococcus aureus, Escherichia coli, and Pseudomonas sp., by agar well diffusion method. The capping agents on the surface of magnetite NPs were inefficient to inhibit the growth of bacteria [50].

Zinc oxide nanoparticle (ZnONPs) without calcinations were developed by green synthesis method using aqueous leaf extracts of $A$. indica. The formed NPs were characterized by scanning electron microscopy (SEM), X-ray diffraction (XRD), Fourier-transform infrared spectrometer (FTIR), and energy dispersive analysis of X-rays (EDAX) for its morphology, size, crystallinity, and percentage composition. The results confirmed the formation of nanoflowers of $51 \mathrm{~nm}$. This ZnONPs could be used as an inexpensive and effective adsorbent for the removal of arsenic ions from aqueous solution [51]. ZnO nanotubes were successfully fabricated using neem leaf extract. $\mathrm{ZnO}$ nanotubes were characterized by SEM and XRD. The final product was highly crystalline with the size of $25 \mathrm{~nm}$. ZnONPs showed a significant antibacterial activity against E. coli with zone of inhibition of $12 \mathrm{~mm} \mathrm{[52].} \mathrm{ZnO}$ is non-toxic and used in industrial sectors including environmental, synthetic textiles, food, packaging, medical care, healthcare, as well as construction and decoration [53]

A. indica plant-mediated process was developed for the synthesis of titanium NPs from titanium dioxide [54] and titanium isopropoxide [55]. The titanium NPs were spherical in shape and the size ranged from 15 to $42 \mathrm{~nm}$ [54].

\section{Synthesis of AgNPs using neem extract}

Silver is one of the most commercialized nanomaterials with 500 tons of AgNPs production per year [56] and is estimated to increase in next few years. Including its profound role in the field of high sensitivity biomolecular detection, catalysis, biosensors, and medicine; it has been acknowledged to have strong inhibitory and bactericidal effects along with the antifungal, anti-inflammatory, and anti-angiogenesis activities $[31,57]$. AgNPs have unique optical, electrical, and thermal properties that play an indispensable role in drug delivery, diagnostics, imaging, sensing, gene delivery, artificial implants, and tissue engineering [58].

A number of techniques are available for the synthesis of AgNPs such as ion sputtering, chemical reduction, and sol-gel. [37,38,40,59]. However, these methods also result in contaminants during the synthesis procedures or in later applications with associated limitations. AgNPs can be produced at low concentration of leaf extract without using any additional harmful chemical/physical methods. This greener synthesis of AgNPs is one-step, cost-effective, environmentfriendly, and relatively reproducible and often results in more stable materials [60]. This eco-friendly method could be a competitive alternative to the conventional physical/chemical methods used for the synthesis of silver nanoparticle and has a potential to be used in biomedical applications and will play an important role in optoelectronics and medical devices in near future.

AgNPs, due to their antimicrobial properties, have been used most widely in the health industry, medicine, textile coatings, food storage, dye reduction, wound dressing, antiseptic creams, and a number of environmental applications [61]. Since ancient times, elemental silver and its compounds have been used as antimicrobial agents and was used to preserve water in the form of silver coins/silver vessels [38,62]. Antibacterial properties of silver are documented since 1000 B.C. when silver vessels were used to preserve water $[63,64]$.
Silver ions $(\mathrm{Ag}+)$ and its compounds are highly toxic to microorganisms exhibiting strong biocidal effects on many species of bacteria but have a low toxicity toward animal cells [65]. Bacterial cells exposed to the Ag+ ions activate stress response that leads to the condensation of DNA in the center of the cell, and this condensation of DNA prevents cell replication by preventing the DNA from being accessed by transcriptional enzymes such as DNA polymerase. It can also cause cell membrane detachment from the cell wall, cell wall damage, and electron dense granules composed of silver outside and, in some instances, inside the cell [66]. AgNPs anchor to and penetrate the cell wall of bacteria [67], suggesting that the resultant structural change in the cell membrane could cause an increase in cell permeability, leading to an uncontrolled transport through the cytoplasmic membrane, and ultimately cell death. Silver inactivates proteins by binding to sulfur-containing compounds [68]. It was also reported that treating cells with silver leads to cell shrinkage and dehydration [69]. It has also been proposed that the antibacterial mechanism of AgNPs is related to the formation of free radicals and subsequent free radical-induced membrane damage $[70,71]$. However, it has been reported that AgNPs are non-toxic to humans though most effective against virus, bacteria, and other eukaryotic microorganisms even at low concentrations without any side effects [72].

AgNPs are synthesized by reducing silver ion using reducing agents present in neem extract and are characterized by UV-visible spectrophotometer, particle size analyzer (DLS), SEM, transmission electron microscopy, energy-dispersive spectroscopy, XRD analysis, nanoparticle tracking analyzer analysis, and FTIR analysis [5,33,73-75]. Transformation of silver ions into AgNPs during exposure to the neem leaf extract is followed by color change from pale yellow to dark yellowish brown color in aqueous solution [1]. Studies have indicated that the reducing phytochemicals in the neem leaf consisted mainly of terpenoids. It was found that these reducing components also served as capping and stabilizing agents in addition to reduction as revealed from FTIR studies [76].

\section{Antimicrobial activity of neem synthesized AgNPs}

Studies showed that the surgical masks coated with AgNPs had antibacterial properties. Nanoparticle-coated masks were capable of $100 \%$ reduction in viable $E$. coli and $S$. aureus cells after incubation. In addition, the study reported no signs of skin irritation in any of the persons wearing the masks [77]. Biosynthetic production of AgNPs by aqueous extract of neem leaves $(20 \% \mathrm{w} / \mathrm{v})$ and $0.01 \mathrm{M}$ silver nitrate $\left(\mathrm{AgNO}_{3}\right)$ solution in 1:4 mixing ratio and its bactericidal effect in cotton cloth against $E$. coli by disk diffusion method were studied. The results demonstrated the antibacterial activity, and thereby possible use of cotton cloths incorporated with biologically synthesized AgNPs for wound dressing [78].

The growth of gentamycin and ampicillin-resistant Klebsiella pneumoniae, gentamicin and piperacillin-resistant Salmonella typhi, fluconazole-resistant Candida albicans, and multiple drug-resistant E. coli was inhibited by neem synthesized AgNPs. The average size of AgNPs synthesized using neem leaves extract was $43 \mathrm{~nm}$ [73]. Neemmediated biosynthesized NPs, in the size of around 70-80 nm, showed significant inhibition of urinary tract infection (UTI) pathogens such as $S$. aureus, Proteus sp., Pseudomonas sp., and E. coli [79]. Green synthesized AgNPs from $1 \mathrm{mM} \mathrm{AgNO}$ solution through aqueous leaf extract of neem showed antibacterial activity against S. typhi and Klebsiella pneumoniae [80]. AgNPs were prepared using aqueous neem leaf extract and $\mathrm{AgNO}_{3}$ solution at room temperature. The synthesized NPs were coated on polyurethane foams (PU) by overnight exposure to the aqueous solution. Several rounds of washing and air drying resulted in stable PU foam with uniform coating. This silver nanoparticle-coated PU was capable of removing the complete load of bacteria (E. coli, S. aureus, and Pseudomonas aeruginosa) from water samples with initial load of $1 \times 10^{5}$ and $1 \times 10^{6} \mathrm{CFU} / \mathrm{ml}$, after a contact time of $30 \mathrm{~min}$. The water treated with the control sample (pure PU) showed substantial growth on the plates. Even after the treatment of $30 \mathrm{~min}$, the AgNPs were found to have stable binding with PU and did not mix with water [5]. 
AgNPs synthesized from neem leaves were tested for their antimicrobial activity against Gram-positive ( $S$. aureus) and Gram-negative (E. coli) bacteria. AgNPs rendered high antimicrobial efficacy and the zone of inhibition observed against $S$. aureus and E. coli was around 10 $\mathrm{mm}$ and $12 \mathrm{~mm}$ for $50 \mu \mathrm{g} / \mathrm{ml}$ and $13 \mathrm{~mm}$ and $15 \mathrm{~mm}$ for $100 \mu \mathrm{g} / \mathrm{ml}$, respectively [58]. AgNPs synthesized using aqueous leaf extract of neem and aqueous solution ( $1 \mathrm{mM})$ of $\mathrm{AgNO}_{3}$ were effectively accessed against Gram-positive (Bacillus sp.) and Gram-negative (E. coli) bacteria. The inhibition zones obtained indicated maximum antibacterial activity of the prepared NPs over the plant extract or $\mathrm{AgNO}_{3}$ solution used individually [33]. AgNPs using leaf extracts of $A$. indica were synthesized and estimation of antimicrobial activity was conducted in vitro by disc diffusion method against E. coli (MTCC 448). It was observed that NPs exerted higher zone of inhibition than the $\mathrm{AgNO}_{3}$ solution [43]. AgNPs were synthesized using neem leaves extract and $\mathrm{AgNO}_{3}(1 \mathrm{mM})$ solution. The synthesized AgNPs were found to possess an effective antibacterial property against E. coli [15]. AgNPs were synthesized using neem leaf extract and its antibacterial activity against disease-causing bacteria B. subtilis, Klebsiella planticola, K. Pneumoniae, Staphylococcus sp., and $E$. coli was analyzed. At $90 \mu \mathrm{l}$ concentration synthesized AgNPs exhibited significant antibacterial activity against all the tested bacteria which was better than ampicillin [81].

AgNPs synthesized from $1 \mathrm{mM} \mathrm{AgNO}_{3}$ solution and aqueous leaf extract of neem showed zone of inhibition against Gram-positive (Micrococcus sp., Bacillus sp., and Staphylococcus sp.) and Gram-negative (Klebsiella sp. and E. coli) bacteria. The activity observed was similar to that of the standard antibiotics tested. The size of synthesized silver nanoparticle was $146 \mathrm{~nm}$ [76]. AgNPs were synthesized using aqueous extract of neem leaves and silver salt. Maximum zone of clearance of $6 \mathrm{~mm}$ was observed at $12 \mathrm{mg} / \mathrm{ml}$ of AgNPs [44]

\section{CONCLUSION}

Synthesis of NPs using neem extract provides the single-step process for biosynthesis of NPs. This method is environment-friendly and commercially economic. Green synthesized NPs, especially the neem synthesized AgNPs, are found to have enhanced antibacterial activity. Due to the enhanced antimicrobial activity, it could be effectively used in the field of medicine as well as in food and cosmetic industries. However, further, progresses are desirable for the rational practical approach.

\section{REFERENCES}

1. Vivehananthan K, Sudha Lakshmi SY, De Silva WH, Kumar SA. Silver nanoparticles of Azadirachta indica: Biological method of synthesis and characterization. World J Pharm Res 2015;4:77-86.

2. Taniguchi N. On the Basic Concept of Nano-Technology. In: Proceedings of International Conference on Product Engineering Part II. Tokyo: Japan Society of Precision Engineering; 1974. p. 18-23.

3. Taylor BN, editors. The International Systems of Units (SI). Washington, DC: United States Department of Commerce, National Institute of Standards and Technology, NIST Special Publication; 2001. p. 330 .

4. Prathna TC, Mathew L, Chandrasekaran N, Raichur AM, Mukherjee A. Biomimetic synthesis of nanoparticles: Science, technology and applicability. In: Mukherjee A, editor. Biomimetics Learning from Nature. 2010. Available from: http://www.InTechOpen.com/books.

5. Namratha N, Monica PV. Synthesis of silver nanoparticles using Azadirachta indica (Neem) extract and usage in water purification. Asian J Pharm Tech 2013;3:170-4

6. Ingale AG, Chaudhari AN. Biogenic synthesis of nanoparticles and potential applications: An eco-friendly approach. J Nanomed Nanotechol 2013;4:165.

7. Ahmad A, Mukherjee P, Senapati S, Mandal D, Khan MI, Kumar R. Extracellular biosynthesis of silver nanoparticles using the fungus Fusarium oxysporum. Colloids Surf B 2003;28:313-8.

8. Jacob J, Kapoor S, Biswas N, Mukherjee T. Size tunable synthesis of silver nanoparticles in water-ethylene glycol mixtures. Colloids Surf A 2007;301:329-34.

9. Sharma VK, Yngard RA, Lin Y. Silver nanoparticles: Green synthesis and their antimicrobial activities. Adv Colloid Interface Sci
2009; 145:83-96.

10. Qiaoxin Z, Hao L, Xiaohui W, Xiaoliang S, Xinglong D. Fabrication and characterization of nanosilver powder prepared by spray pyrolysis. J Wuhan Univ Technol Mater Sci 2009;24:871-4.

11. Tavakoli A, Sohrabi M, Kargari A. A review of methods for synthesis of nanostructured metals with emphasis on iron compounds. Chem Pap 2007;61:151-70.

12. Ahmed S, Ahmad M, Swami BL, Ikram S. Plants extract mediated synthesis of silver nanoparticles for antimicrobial applications: A green expertise. J Adv Res 2016;7:17-28.

13. Antony E, Gunasekaran S, Sathiavelu M, Arunachalam S. A review on use of plant extracts for gold and silver nanoparticle synthesis and their potential activities against food pathogens. Asian J Pharm Clin Res 2016;9:18-23.

14. Sun Y, Xia Y. Shape-controlled synthesis of gold and silver nanoparticles. Science 2002;298:2176-9

15. Resmi CR, Sreejamol P, Pillai P. Green synthesis of silver nanoparticles using Azadirachta indica leaves extract and evaluation of antibacterial activities. Int J Adv Biol Res 2014;4:300-3

16. Thirumurugan A, Aswitha P, Kiruthika C, Nagarajan S, Christy AN. Green synthesis of platinum nanoparticles using Azadirachta indica-an eco-friendly approach. Mater Lett 2016;170:175-8.

17. Konishi Y, Ohno K, Saitoh N, Nomura T, Nagamine S. Microbial synthesis of gold nanoparticles by metal reducing bacterium. Trans Mater Res Soc Jpn 2004;29:2341-3.

18. Ahmad A, Senapati S, Khan MI, Kumar R, Sastry M. Extracellular biosynthesis of monodisperse gold nanoparticles by a novel extremophilic actinomycete, Thermomonospora sp. Langmuir 2003; 19:3550-3

19. Balagurunathan R, Radhakrishnan M, Rajendran RB, Velmurugan D. Biosynthesis of gold nanoparticles by actinomycete Streptomyces viridogens strain HM10. Indian J Biochem Biophys 2011;48:331-5.

20. Lengke M, Fleet M, Southam G. Biosynthesis of silver nanoparticles by filamentous cyanobacteria from a silver(I) nitrate complex. Langmuir 2006;10:1021-30.

21. Bhainsa KC, D'Souza SF. Extracellular biosynthesis of silver nanoparticles using the fungus Aspergillus fumigatus. Colloids Surf B Biointerfaces 2006;47:160-4

22. Mukherjee P, Roy M, Mandal BP, Dey GK, Mukherjee PK, Ghatak $\mathrm{J}$, et al. Green synthesis of highly stabilized nanocrystalline silver particles by a non-pathogenic and agriculturally important fungus $T$. asperellum. Nanotechnology 2008;19:075-103.

23. Ravindra BK, Rajasab AH. Silver nanoparticles synthesis from different fungal species and their antifungal effect. Int J Pharm Pharm Sci 2015;7:165-70.

24. Marshall MJ, Beliaev AS, Dohnalkova AC, Kennedy DW, Shi L, Wang Z, et al. C-type cytochrome-dependent formation of U(IV) nanoparticles by Shewanella oneidensis. PLoS Biol 2006;4:e268.

25. Prasad K, Jha AK, Kulkarni AR. Lactobacillus assisted synthesis of titanium nanoparticles. Nanoscale Res Lett 2007;2:248-50.

26. Kirthi AV, Rahuman AA, Rajakumar G, Marimuthu S, Santhoshkumar T, Jayaseelan C, et al. Biosynthesis of titanium dioxide nanoparticles using bacterium Bacillus subtilis. Mater Lett 2011;65:2745-7.

27. Chandran SP, Chaudhary M, Pasricha R, Ahmad A, Sastry M. Synthesis of gold nanotriangles and silver nanoparticles using Aloe vera plant extract. Biotechnol Prog 2006;22:577-83

28. Bar H, Bhui DK, Sahoo GP, Sarkar P, De SP, Misra A. Green synthesis of silver nanoparticles using latex of Jatropha curcas. Colloids Surf A 2009;339:134-9.

29. Krishnaraj C, Jagan EG, Rajasekar S, Selvakumar P, Kalaichelvan PT, Mohan N, et al. Synthesis of silver nanoparticles using Acalypha indica leaf extracts and its antibacterial activity against water borne pathogens. Colloids Surf B Biointerfaces 2010;76:50-6.

30. Nabikhan A, Kandasamy K, Raj A, Alikunhi NM. Synthesis of antimicrobial silver nanoparticles by callus and leaf extracts from saltmarsh plant, Sesuvium portulacastrum L. Colloids Surf B Biointerfaces 2010;79:488-93.

31. Veerasamy R, Xin TZ, Gunasagaran S, Xiang TF, Yang EF, Jeyakumar N, et al. Biosynthesis of silver nanoparticles using Mangosteen leaf extract and evaluation of their antimicrobial activities. J Saudi Chem Soc 2011;15:113-20.

32. Logeswari P, Silambarasan S, Abraham J. Synthesis of silver nanoparticles using plants extract and analysis of their antimicrobial property. J Saudi Chem Soc 2012;19:311-7.

33. Banerjee P, Satapathy M, Mukhopahayay A, Das P. Leaf extract 
mediated green synthesis of silver nanoparticles from widely available Indian plants: Synthesis, characterization, antimicrobial property and toxicity analysis. Bioresour Bioprocess 2014;1:3.

34. Kumar SA, Ravi S, Velmurugan S. Green synthesis of silver nanoparticles from Gloriosa superba L. leaf extract and their catalytic activity. Spectrochim Acta A Mol Biomol Spectrosc 2013;115:388-92.

35. Logeswari P, Silambarasan S, Abraham J. Ecofriendly synthesis of silver nanoparticles from commercially available plant powders and their antibacterial properties. Sci Iran 2013;20:1049-54.

36. Ghaffari-Moghaddam M, Hadi-Dabanlou R. Plant mediated green synthesis and antibacterial activity of silver nanoparticles using Crataegus douglasii fruit extract. J Indus Eng Chem 2014;20:739-44.

37. Bindhu MR, Umadevi M. Antibacterial and catalytic activities of green synthesized silver nanoparticles. Spectrochim Acta A Mol Biomol Spectrosc 2015;135:373-8

38. Padalia H, Moteriya P, Chanda S. Green synthesis of silver nanoparticles from marigold flower and its synergistic antimicrobial potential. Arab J Chem 2015;8:732-41.

39. Sadeghi B, Gholamhoseinpoor F. A study on the stability and green synthesis of silver nanoparticles using Ziziphora tenuior $(\mathrm{Zt})$ extract at room temperature. Spectrochim Acta A Mol Biomol Spectrosc 2015;134:310-5.

40. Sridevi A, Sandhya A, Suvarnalatha Devi P. Characterization and antibacterial studies of leaf assisted silver nanoparticles from Carica papaya: A green synthetic approach. Int J Pharm Pharm Sci 2015;7:143-6.

41. Kalaiyarasu T, Karthi N, Gowri VS, Manju V. In vitro assessment of antioxidant and antibacterial activity of green synthesized silver nanoparticles from Digitaria radicosa leaves. Asian J Pharm Clin Res 2016;9:297-302

42. Girish K. Antimicrobial activities of Lantana camara Linn. Asian J Pharm Clin Res 2017;10:57-67.

43. Gujral SS. Synthesis and characterization of Gold and Silver nanoparticles using different leaf extracts namely Catharanthus roseus, Datura metel and Azadirachta indica and estimation of antimicrobial activity of silver nano-particles using disc diffusion method. Int J Drug Dev Res 2014;6:222-32.

44. Verma A, Mehata MS. Controllable synthesis of silver nanoparticles using Neem leaves and their antimicrobial activity. J Radiat Res Appl Sci 2016;9:109-15

45. Girish K, Shankara Bhat. Neem-a green treasure. Electron J Biol 2008;4:102-11

46. Shankar SS, Rai A, Ahmad A, Sastry M. Rapid synthesis of Au, Ag, and bimetallic Au core-Ag shell nanoparticles using neem (Azadirachta indica) leaf broth. J Colloid Interface Sci 2004;275:496-502.

47. Thirumurugan A, Jiflin GJ, Rajagomathi G, Tomy NA, Ramachandran S, Jaiganesh R. Biotechnological synthesis of gold nanoparticles of Azadirachta indica leaf extract. Int J Biol Technol 2010;1:75-7

48. Bindhani BK, Panigrahi AK. Green synthesis of gold nanoparticles using neem (Azadirachta indica L.) leaf extract and its biomedical applications. Int J Adv Biotechnol Res 2014;5:457-64.

49. Pattanayak M, Nayak PL. Green synthesis and characterization of zero valent iron nanoparticles from the leaf extract of Azadirachta indica (neem). World J Nano Sci Technol 2013;2:6-9.

50. Rajendran K, Sen S. Effect of capping agent on antimicrobial activity of nanoparticles. Pharm Lett 2015;7:37-42.

51. Gnanasangeetha D, Sarala DT. Facile and eco-friendly method for the synthesis of zinc oxide nanoparticles using Azadirachta and Emblica. Int J Pharm Sci Res 2014;5:2866-73.

52. Oudhia A, Kulkarni P, Sharma S. Green synthesis of ZnO nanotubes for bioapplications. Int J Adv Eng Res Stud 2015;4:280-1.

53. Noorjahan CM, Jasmine Shahina SK, Deepika T, Rafiq S. Green synthesis and characterization of zinc oxide nanoparticles from neem (Azadirachta indicia). Int J Sci Eng Technol Res 2015;4:5751-3.

54. Krishnasamy A, Sundaresan M, Velan P. Rapid phytosynthesis of nanosized titanium using leaf extract of Azadirachta indica. Intl J ChemTech Res 2015;8:2047-52.

55. Sankar R, Rizwana K, Shivashangari KS, Ravikumar V. Ultra-rapid photocatalytic activity of Azadirachta indica engineered colloidal titanium dioxide nanoparticles. Appl Nanosci 2015;5:731-36.

56. Larue C, Castillo-Michel H, Sobanska S, Cécillon L, Bureau S, Barthès $\mathrm{V}$, et al. Foliar exposure of the crop Lactuca sativa to silver nanoparticles: Evidence for internalization and changes in ag speciation. J Hazard Mater 2014;264:98-106.

57. El-Chaghaby GA, Ahmad AF. Biosynthesis of silver nanoparticles using
Pistacia lentiscus leaves extract and investigation of their antimicrobial effect. Oriental J Chem 2011;27:929-36.

58. Sharma S, Kumar S, Bulchandini BD, Taneja S, Banyal S. Green synthesis of silver nanoparticles and their antimicrobial activity against gram positive and gram negative bacteria. Int J Biotechnol Bioeng Res 2013;4:341-6.

59. Pourmortazavi SM, Taghdiri M, Makari V, Rahimi-Nasrabadi M. Procedure optimization for green synthesis of silver nanoparticles by aqueous extract of Eucalyptus oleosa. Spectrochim Acta A Mol Biomol Spectrosc 2015;136:1249-54.

60. Mittal J, Batra A, Singh A, Sharma MM. Phytofabrication of nanoparticles through plant as nanofactories. Adv Nat Sci Nanosci Nanotechnol 2014;5:043002.

61. Gao X, Yourick JJ, Topping VD, Black T, Olejnik N, Keltner Z, et al. Toxicogenomic study in rat thymus of $\mathrm{F} 1$ generation offspring following maternal exposure to silver ion. Toxicol Rep 2015;2:341-50.

62. Devi LS, Joshi SR. Ultrastructures of silver nanoparticles biosynthesized using endophytic fungi. J Microsc Ultrastruc 2015;3:29-37.

63. Richard JW, Spencer BA, McCoy LF, Carina E, Washington J, Edgar P. Acticoat versus silver ion: The truth. J Burns Surg Wound Care 2002;1:11-20.

64. Castellano JJ, Shafii SM, Ko F, Donate G, Wright TE, Mannari RJ, et al. Comparative evaluation of silver-containing antimicrobial dressings and drugs. Int Wound J 2007;4:114-22.

65. Prema P. Chemical mediated synthesis of silver nanoparticles and its potential antibacterial application. In: Carpi A, editor. Progress in Molecular and Environmental Bioengineering-From Analysis and Modeling to Technology Applications. 2011. Available from: http:// www.InTechOpen.com/books.

66. Feng QL, Wu J, Chen GQ, Cui FZ, Kim TN, Kim JO, et al. A mechanistic study of the antibacterial effect of silver ions on Escherichia coli and Staphylococcus aureus. J Biomed Mater Res 2000;52:662-8.

67. Morones JR, Elechiguerra JL, Camacho A, Holt K, Kouri JB, Ramirez JT, et al. The bactericidal effect of silver nanoparticles. Nanotechnol 2005; 16:2346-53.

68. Klueh U, Wagner V, Kelly S, Johnson A, Bryers JD. Efficacy of silver coated fabric to prevent bacterial colonization and subsequent device based biofilm formation. J Biomed Mater Res B Appl Biomater 2000;53:621-31.

69. Guggenbichler JP, Boswald M, Lugauer S, Krall T. A new technology of micro dispersed silver in polyurethane induces antimicrobial activity in central venous catheters. Infection 1999;27:16-23.

70. Danilczuk M, Lund A, Sadlo J, Yamada H, Michalik J. Conduction electron spin resonance of small silver particles. Spectrochim Acta A Mol Biomol Spectrosc 2006;63:189-91.

71. Kim JS, Kuk E, Yu KN, Kim JH, Park SJ, Lee HJ, et al. Antimicrobial effects of silver nanoparticles. Nanomed Nanotechnol Biol Med 2007;3:95-101

72. Jeong SH, Yeo SY, Yi SC. The effect of filler particles size on the antibacterial properties of compounded polymer or silver fiber. J Mater Sci 2005;40:5407-11.

73. Gavhane AJ, Padmanabhan P, Kamble SP, Jangle SN. Synthesis of silver nanoparticles using extract of neem leaf and triphala and evaluation of their antimicrobial activities. Int J Pharm Bio Sci 2012;3:88-100.

74. Mathur A, Kushwaha A, Dalakoti V, Dalakoti G, Singh DS. Green synthesis of silver nanoparticles using medicinal plant and its characterization. Der Pharm Sin 2014;5:118-22.

75. Ahmed S, Ahmad M, Swami BL, Ikram S. Green synthesis of silver nanoparticles using Azadirachta indica aqueous leaf extract. J Radiat Res Appl Sci 2016;9:1-7.

76. Sajesh Kumar NK, Vazhacharickal PJ, Mathew JJ, Joy J. Synthesis of silver nano particles from neem leaf (Azadirachta indica) extract and its antibacterial activity. CIBTech J Biotechnol 2015;4:20-31.

77. Li Y, Leung P, Yao L, Song QW, Newton E. Antimicrobial effect of surgical masks coated with nanoparticles. J Hosp Infect 2006;62:58-63.

78. Tripathi A, Chandrasekaran N, Raichur AM, Mukherjee A. Antibacterial applications of silver nanoparticles synthesized by aqueous extract of Azadirachta indica (Neem) leaves. J Biomed Nanotechnol 2009;5:93-8.

79. Vijayameena C, Kavitha K. Studies and evaluation of phytosynthetic silver nanoparticles against UTI causing pathogens. Int J Curr Biotechnol 2013;1:22-4.

80. Lalitha A, Subbaiya R, Ponmurugan P. Synthesis of silver nanoparticles from leaf extract Azhadirachta indica and to study its anti-bacterial and antioxidant property. Int J Curr Microbiol App Sci 2013;2:228-35.

81. Shanthi D, Kalaimathi J. Plant-mediated synthesis of silver nanoparticles using neem leaf extracts and its antibacterial activity. Int J Inst Pharm Life Sci 2014;4:40-6. 